\title{
ISOBOLOGRAPHIC ASSESSMENT OF INTERACTIONS BETWEEN RETIGABINE AND PHENYTOIN IN THE MOUSE MAXIMAL ELECTROSHOCK-INDUCED SEIZURE MODEL AND CHIMNEY TEST
}

\section{IZOBOLOGRAFICZNE OSZACOWANIE INTERAKCJI POMIĘDZY RETIGABINA A FENYTOINĄ W MYSIM MODELU DRGAWEK WYWOŁYWANYCH MAKSYMALNYM WSTRZĄSEM ELEKTRYCZNYM I TEŚCIE KOMINA}

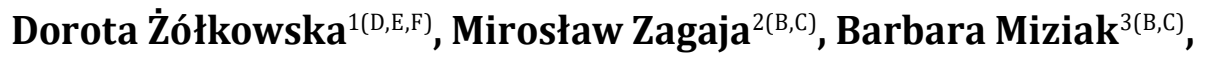 \\ Maria W. Kondrat-Wróbel ${ }^{3(B, C)}$, Katarzyna Załuska ${ }^{3(B, C)}$, Magdalena Florek-Luszczki ${ }^{4(D, E, F)}$, \\ Monika Szpringer $^{5(\mathrm{D}, \mathrm{E}, \mathrm{F})}$, Bartłomiej Drop ${ }^{3(\mathrm{C}, \mathrm{D}, \mathrm{E}, \mathrm{F})}$, Marek Zadrożniak ${ }^{6(\mathrm{C}, \mathrm{D}, \mathrm{E}, \mathrm{F})}$, \\ Stanisław J. Czuczwar ${ }^{3(D, E, F, G)}$, Jarogniew J. Luszczki ${ }^{3(A, D, E, F, G)}$
}

${ }^{1}$ University of California Davis School of Medicine, Sacramento, United States of America ${ }^{2}$ Institute of Rural Health, Isobolographic Analysis Laboratory, Lublin, Poland

${ }^{3}$ Medical University of Lublin, Department of Pathophysiology, Poland

${ }^{4}$ Institute of Rural Health, Centre of Public Health and Health Promotion, Lublin, Poland ${ }^{5}$ The Jan Kochanowski University in Kielce, Faculty of Medicine and Health Sciences, Poland ${ }^{6}$ Medical University of Lublin, Department of Otolaryngology, Poland

Authors' contribution Wkład autorów: A. Study design/planning zaplanowanie badań B. Data collection/entry zebranie danych C. Data analysis/statistics dane - analiza i statystyki D. Data interpretation interpretacja danych E. Preparation of manuscript przygotowanie artykułu F. Literature analysis/search wyszukiwanie i analiza literatury G. Funds collection zebranie funduszy

\section{Summary}

Background. Search for beneficial combinations of antiepileptic drugs (AEDs) that can be used in patients with pharmacoresistant epilepsy, is still conducted both empirically and rationally, based on molecular mechanisms of AEDs' action. This study was aimed at characterizing the interaction profiles for the combination of two AEDs (i.e., retigabine [RTG] and phenytoin [PHT]) in the maximal electroshock-induced seizures (MES) and chimney test (motor performance) in adult male albino Swiss mice. Material and methods. Type I isobolographic analysis was used to determine interactions for the combination of RTG with PHT (at three fixed-ratios of 1:3, 1:1 and 3:1) with respect to its anticonvulsant and acute neurotoxic effects in the MES and chimney tests, respectively. Total brain concentrations of RTG and PHT were estimated to exclude any pharmacokinetic interaction between AEDs. Results. The combination of RTG with PHT at the fixed-ratios of 1:3, 1:1 and 3:1 produced additive interactions in both, the MES and chimney tests. RTG and PHT did not affect each other their total brain concentrations in mice, confirming pharmacodynamic interaction between the investigated drugs. Conclusions. The combination of RTG with PHT was neutral suggesting that this two-drug combination might occur favorable in some patients with refractory epilepsy.

Keywords: drug interactions, isobolographic analysis, phenytoin, retigabine

\section{Streszczenie}

Wprowadzenie. Poszukiwanie korzystnych kombinacji leków przeciwpadaczkowych (LPP), które mogą być zastosowane u pacjentów z padaczką lekooporną, jest wciąż przeprowadzane zarówno empirycznie jak i racjonalnie, w oparciu o molekularne mechanizmy działania LPP. Celem badania było scharakteryzowanie profilów interakcji kombinacji dwóch leków (tj. retigabiny [RTG] i fenytoiny [PHT]) w teście drgawek wywoływanych maksymalnych wstrząsem elektrycznym (MES) i w teście komina (koordynacja ruchowa) u dorosłych samców myszy szczepu Albino Swiss. Materiał i metody. Typ I analizy izobolograficznej był zastosowany aby wyznaczyć typy interakcji dla kombinacji RTG z PHT (w trzech stałych proporcjach dawek 1:3, 1:1 i 3:1) w odniesieniu do jej działań przeciwdrgawkowych i ostrych działaniach niepożądanych (neurotoksycznych) odpowiednio w testach MES i komina. Całkowite stężenia mózgowe RTG i PHT były oceniane, aby wykluczyć interakcje farmakokinetyczną pomiędzy LPP. Wyniki. Wyniki wskazują, że kombinacja RTG z PHT w stałych proporcjach dawek 1:3, 1:1 i 3:1 wykazuje interakcje addytywne w obu testach MES i komina. RTG i PHT nie wpływały wzajemnie na swe całkowite stężenia mózgowe u myszy, potwierdzając interakcję farmakodynamiczną pomiędzy badanymi lekami. Wnioski. Przedkliniczny profil dla kombinacji RTG z PHT jest neutralny, sugerując, że ta dwulekowa kombinacja mogłaby okazać się korzystna u niektórych pacjentów z padaczką lekooporną.
Tables: 1
Figures: 2

References: 22

Submitted: 09.09.2015

Accepted: 17.10.2016

Słowa kluczowe: interakcje lekowe, analiza izobolograficzna, fenytoina, retigabina

Zolkowska D, Zagaja M, Miziak B, Kondrat-Wrobel MW, Zaluska K, Florek-Luszczki M, Szpringer M, Drop B, Zadrozniak M, Czuczwar S, Luszczki JJ. Isobolographic assessment of interactions between retigabine and phenytoin in the mouse maximal electroshock-induced seizure model and chimney test. Health Problems of Civilization. 2016; 10(4): 54-59. doi: 10.5114/hpc.2016.63572.

Address for correspondence / Adres korespondencyjny: Jarogniew J. Łuszczki, Medical University of Lublin, Department of Pathophysiology, Jaczewskiego 8b, 20-090 Lublin, Poland, e-mail: jarogniew.luszczki@umlub.pl, phone: +48 814486500

Copyright: (C) 2016 Pope John Paul II State School of Higher Education in Biała Podlaska, Dorota Żółkowska, Mirosław Zagaja, Barbara Miziak, Maria W. KondratWróbel, Katarzyna Załuska, Magdalena Florek-Łuszczki, Monika Szpringer, Bartłomiej Drop, Marek Zadrożniak, Stanisław J. Czuczwar, Jarogniew J. Łuszczki. This is an Open Access journal, all articles are distributed under the terms of the Creative Commons Attribution-NonCommercial-ShareAlike 4.0 International (CC BY-NCSA 4.0) License (http://creativecommons.org/licenses/by-nc-sa/4.0/), allowing third parties to copy and redistribute the material in any medium or format and to remix, transform, and build upon the material, provided the original work is properly cited and states its license. 


\section{Background}

Despite a large number of antiepileptic drugs (AEDs) currently available in the market to treat epilepsy patients, there are some patients ( $30 \%)$, who are insufficiently medicated with these AEDs in monotherapy [1]. For these patients, some novel treatment options are necessary to stop their seizure attacks so as to improve their quality of lives [1, 2]. Of these options, one can distinguish: application of AEDs in combination (as add-on therapy or polytherapy), application of novel antiseizure compounds either synthesized chemically or isolated from herbs and medicinal plants, application of various herbal remedies from folk medicine along with AEDs, and others [3, 4].

Retigabine (RTG) is a third-generation antiepileptic drug (AED) that has been licensed as a drug in add-on therapy for patients aged 18 years or older with drug-resistant partial-onset seizures with or without secondary generalization, where other appropriate AED combinations have proved inadequate or have not been tolerated [5]. Unique molecular mechanisms of action of RTG are based on a selective M-current potassium channel opening effect and modulation of extra-synaptic $\mathrm{GABA}_{\mathrm{A}}$ receptors containing $\delta$-subunit $[6,7]$.

In preclinical in vivo studies based on isobolographic analysis of interaction, it has previously been documented that the combination of RTG with valproate produced supra-additive (synergistic) interaction, while RTG combined with carbamazepine and lamotrigine exerted additive interaction in the mouse MES model [8]. Only RTG combined with levetiracetam exerted both, additive and supra-additive interactions, depending on the tested drug dose ratio combinations, in the mouse MES model [9]. Additionally, these AED combinations have been confirmed in clinical settings as effective adjunctive therapies in patients with uncontrolled partial-onset seizures [10].

The aim of this study was to continue our preclinical experiments and characterize preclinical profile for the combination of RTG with phenytoin (PHT - a commonly used classical AED) in the maximal electroshock-induced seizure (MES) model and chimney test in mice by the use of type I isobolographic analysis of interaction. The choice of PHT in combination with RTG was based on clinical presumptions concerning the use of these AEDs in patients with tonic-clonic seizures and partial onset seizures [1]. Of note, the mouse MES model is thought to be an experimental model of tonic-clonic seizures and partial convulsions with or without secondary generalization in humans [11]. Similarly, the chimney test in rodents can be considered as a model of acute adverse (neurotoxic) effects of AEDs with respect to their potency to produce sedation and ataxia manifesting in mice as impairment of motor coordination in the chimney test [12].

In this study we evaluated isobolographically both, the anticonvulsant and acute adverse (neurotoxic) effects in experimental animals so as to determine protective indices for RTG and PHT administered alone and benefit indices for the combinations of RTG with PHT as documented earlier [13]. Additionally, to exclude any pharmacokinetic interaction between AEDs, total brain concentrations of RTG and PHT were measured.

\section{Materials and methods}

All experiments were conducted on adult male Swiss mice. The experimental protocols and procedures described below were approved by the local ethics committee for animal experiments at the Medical University of Lublin and conformed to the Guide for the Care and Use of Laboratory Animals (License No.: 28/2007). Each experimental group comprised 8 mice. Total number of animals used in this entire study was 224 .

PHT (Sigma-Aldrich) and RTG (GlaxoSmithKline, Brentford, UK) were suspended in a 1\% aqueous solution of Tween 80 (Sigma-Aldrich) in distilled water and administered intraperitoneally (i.p.) as follows: PHT - 120 min, and RTG - 15 min., before the MES and chimney tests and collection of brain tissues for the estimation of AED concentrations.

Maximal electroshock-induced seizures (MES) were produced by an alternating current $(25 \mathrm{~mA}$ and $0.2 \mathrm{~s}$ stimulus duration) delivered via auricular electrodes by a Hugo Sachs stimulator (Rodent Shocker, Freiburg, Germany). Tonic hind limb extension (seizure activity) was taken as the endpoint. The protective activity of RTG and PHT administered alone and in combination was evaluated as the median effective dose values $\left(\mathrm{ED}_{50}\right.$ and $\mathrm{ED}_{50 \text { exp }}$ in $\mathrm{mg} / \mathrm{kg}$ ) against MES-induced seizures, according to Litchfield and Wilcoxon [14], as described elsewhere $[8,15,16]$. The $\mathrm{ED}_{50}$ and $\mathrm{ED}_{50 \text { exp }}$ values represent doses of an $\mathrm{AED}$ alone or two-drug mixtures at the fixed-ratios of 1:3, 1:1 and 3:1 necessary to protect $50 \%$ of the animals tested against MES-induced seizures. Total number of mice used in the MES test was 96.

In the chimney test, impairment of motor coordination in animals manifested as the inability of the mice to climb backward up the transparent plastic tube $(3 \mathrm{~cm}$ inner diameter, $30 \mathrm{~cm}$ length) within 60 seconds [17]. The acute side (neurotoxic) effects of RTG and PHT administered alone and in combination were expressed as median toxic dose values $\left(\mathrm{TD}_{50}\right.$ and $\mathrm{TD}_{50 \text { exp }}$ in $\mathrm{mg} / \mathrm{kg}$ ), i.e., doses of the AEDs administered separately or in 
combination that impaired motor coordination in $50 \%$ of the animals tested. $\mathrm{The} \mathrm{TD}_{50}$ and $\mathrm{TD}_{50 \text { exp }}$ values (representing doses of an AED alone or two-drug mixtures at the fixed-ratios of 1:3, 1:1 and 3:1), were determined in the chimney test by the use of log-probit method [14], as described elsewhere [13, 16]. Total number of mice used in the chimney test was 96.

Test for parallelism of dose-response effects for RTG and PHT administered alone proved that both AEDs had their dose-response effects parallel to each other in the MES and chimney tests, respectively [8]. Thus, interactions between RTG and PHT for three fixed-ratios of 1:3, 1:1 and 3:1 against MES-induced seizures and in the chimney test were analyzed by the use of type I isobolographic analysis for parallel dose-response effects, as described earlier [8]. Briefly, median additive doses for the mixture of RTG with PHT i.e., doses of the mixture, which theoretically should protect $50 \%$ of the animals tested against MES-induced seizures $\left(\mathrm{ED}_{50 \text { add }}\right)$, or should theoretically impair motor coordination in $50 \%$ of the animals tested in the chimney test $\left(\mathrm{TD}_{50 \text { add }}\right)$, were calculated and statistically compared with their corresponding experimentally-derived $\mathrm{ED}_{50 \text { exp }}$ and $\mathrm{TD}_{50 \text { exp }}$ values, as published elsewhere $[8,13,18,19]$. Subsequently, two parameters: protective index (PI - as a ratio of the respective $\mathrm{TD}_{50}$ and $\mathrm{ED}_{50}$ ) and benefit index (BI - as a quotient of $\mathrm{PI}_{\text {exp }}$ and $\mathrm{PI}$ add ) values were calculated, as described elsewhere $[13,16]$. The PI ${ }_{\text {exp }}$ - is the PI calculated from experimentally-determined $\mathrm{ED}_{50}$ and $\mathrm{TD}_{50}$ values, and $\mathrm{PI}_{\text {add }}$ - is the PI calculated from $\mathrm{ED}_{50}$ and $\mathrm{TD}_{50}$ values, which are theoretically accepted as additive.

Total brain concentrations of RTG and PHT were measured for AEDs at the doses corresponding to the fixed-ratio of 1:1 tested in the MES test. Mice were decapitated and their whole brains were removed from skulls, weighed, harvested and homogenized using Abbott buffer (1:2 weight/volume). The homogenates were centrifuged at $10,000 \mathrm{~g}$ for $10 \mathrm{~min}$. Subsequently, the supernatant samples $(200 \mu \mathrm{l})$ containing PHT were analyzed by fluorescence polarization immunoassay (FPIA) using a TDx analyzer (Abbott Laboratories, North Chicago, IL, USA). In contrast, the supernatant samples $(200 \mu \mathrm{l})$ containing RTG were analyzed by high pressure liquid chromatography (HPLC) using an automated HPLC (Dionex, Sunnyvale, CA, USA) system. Total brain AED concentrations are expressed in $\mu \mathrm{g} / \mathrm{ml}$ of brain supernatants for RTG and PHT, as means \pm S.E.M. $(\mathrm{n}=8)$. Total number of mice used in this procedure was 32 .

The unpaired Student's $t$-test was used to statistically compare the $\mathrm{ED}_{50 \text { exp }}$ and $\mathrm{TD}_{50 \exp }$ values with their respective $\mathrm{ED}_{50 \text { add }}$ and $\mathrm{TD}_{50 \text { add }}$ values, as reported earlier $[18,19]$. Similarly, the unpaired Student's $t$-test was used to statistically analyze total brain concentrations of RTG and PHT in experimental animals. Statistical significance was established at $\mathrm{p}<0.05$.

\section{Results}

The $\mathrm{ED}_{50}$ values for RTG and PHT, administered alone in the MES test, were $32.42 \pm 2.50$ and $10.43 \pm 1.41$ $\mathrm{mg} / \mathrm{kg}$, respectively. The test for parallelism of dose-response effects between RTG and PHT revealed that the dose-response effects for both AEDs were parallel to each other. The combination of RTG with PHT (at the fixed-ratios of 1:3, 1:1 and 3:1) produced the defined antiseizure activity in the MES test and the $\mathrm{ED}_{50 \text { exp }}$ values for this combination are shown in Table 1.

Table 1. Combinations of retigabine (RTG) with phenytoin (PHT) at the fixed-ratios of 1:3, 1:1 and 3:1 in the maximal electroshock (MES)-induced seizures and chimney test in mice

\begin{tabular}{|c|c|c|c|c|c|c|c|}
\hline Fixed-ratio & $\mathbf{E D}_{50 \text { add }}$ & $\mathbf{E D}_{\text {50 exp }}$ & TD $_{50 \text { add }}$ & TD $_{\text {50exp }}$ & PI $_{\text {exp }}$ & PI $_{\text {add }}$ & BI \\
\hline $1: 3$ & $15.93 \pm 1.68$ & $14.43 \pm 0.81$ & $45.15 \pm 7.00$ & $55.48 \pm 6.88$ & 3.84 & 2.83 & 1.36 \\
\hline $1: 1$ & $21.42 \pm 1.95$ & $22.72 \pm 2.56$ & $51.63 \pm 7.17$ & $63.64 \pm 7.14$ & 2.80 & 2.41 & 1.16 \\
\hline $3: 1$ & $26.92 \pm 2.22$ & $23.50 \pm 3.46$ & $58.12 \pm 7.34$ & $76.25 \pm 10.70$ & 3.24 & 2.16 & 1.50 \\
\hline & & & & & & & \\
\hline
\end{tabular}

Data are presented as median effective dose $\left(\mathrm{ED}_{50}\right)$ and median toxic dose $\left(\mathrm{TD}_{50}\right)$ values (in $\mathrm{mg} / \mathrm{kg} \pm$ S.E.M.), determined experimentally by log-probit analysis $\left(\mathrm{ED}_{50 \text { exp }}\right.$ or $\left.\mathrm{TD}_{50 \mathrm{exp}}\right)$ or calculated as theoretically additive $\left(\mathrm{ED}_{50 \text { add }}\right.$ or $\left.\mathrm{TD}_{50 \text { add }}\right)$. PI - protective index of RTG and PHT in combinations, as quotients of the respective $\mathrm{TD}_{50}$ and $\mathrm{ED}_{50}$ values, determined experimentally

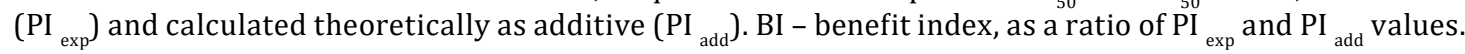

The $\mathrm{TD}_{50}$ values for RTG and PHT, administered separately in the chimney test, were $38.66 \pm 6.83$ and 64.60 $\pm 7.51 \mathrm{mg} / \mathrm{kg}$, respectively. The dose-response effects of RTG and PHT in the chimney test were parallel to one another. The combination of RTG with PHT (at the fixed-ratios of 1:3, 1:1 and 3:1) produced the acute adverse (neurotoxic) effects in the chimney test and the $\mathrm{TD}_{50 \exp }$ values for this combination are shown in Table 1. 
The type I isobolographic analysis of interaction for parallel dose-response effects revealed that all three fixed-ratio combinations of RTG with PHT (1:3,1:1, and 3:1) exerted additive interaction in the MES test in mice (Table 1; Figure 1A). For the mixtures of RTG with PHT at the fixed-ratio combinations of 1:3, 1:1 and 3:1, the $\mathrm{ED}_{50 \text { exp }}$ values did not significantly differ from the corresponding $\mathrm{ED}_{50 \text { add }}$ values (Table 1; Figure $1 \mathrm{~A}$ ). Similarly, the type I isobolographic analysis of interaction for parallel dose-response effects revealed that all three fixed-ratio combinations of RTG with PHT $(1: 3,1: 1$, and 3:1) exerted additive interaction in the chimney test in mice (Table 1; Figure 1B).
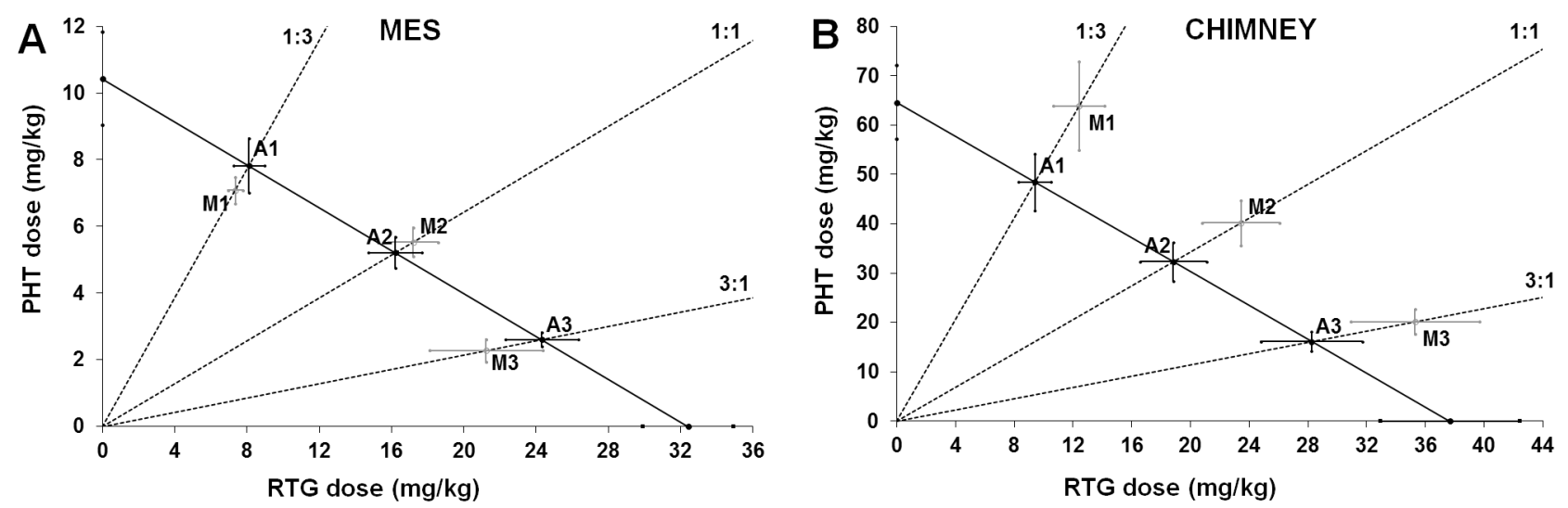

Figure 1A-B. Isobolograms illustrating additive interactions between retigabine (RTG) and phenytoin (PHT) in the maximal electroshock (MES)-induced seizure model and chimney test in mice. The median effective doses $\left(E_{50}-F_{i g}\right.$. A) and median toxic doses $\left(\mathrm{TD}_{50}\right.$ - Fig. B) for RTG and PHT are plotted graphically on the X-and Y-axes, respectively. The solid lines on the $\mathrm{X}$ and $\mathrm{Y}$ axes represent the S.E.M. for the $\mathrm{ED}_{50}$ and $\mathrm{TD}_{50}$ values of the AEDs administered alone. Points $\mathrm{A} 1, \mathrm{~A} 2$ and $\mathrm{A} 3$ depict the theoretically additive $\mathrm{ED}_{50 \text { add }}$ (Fig. $\mathrm{A}$ ) and $\mathrm{TD}_{50 \text { add }}$ (Fig. B) values, whereas points $\mathrm{M} 1, \mathrm{M} 2$ and $\mathrm{M} 3$ represent the experimentally-derived $\mathrm{ED}_{50 \text { exp }}$ and $\mathrm{TD}_{50 \text { exp }}$ values for the fixed-ratio combinations of 1:3, 1:1, and 3:1 that produced $50 \%$ anticonvulsant and acute adverse (neurotoxic) effects in the MES and chimney tests in mice, respectively

For the mixture of RTG with PHT at the fixed-ratio combinations of 1:3, 1:1 and 3:1, the $\mathrm{TD}_{50 \text { exp }}$ values did not significantly differ from the corresponding $\mathrm{TD}_{50 \text { add }}$ values (Figure 1B). The BI values for the combination of RTG with PHT at the fixed-ratio of 1:3, 1:1 and 3:1 were 1.36, 1.16, and 1.50, respectively (Table 1).

Total brain concentrations of PHT $(5.53 \mathrm{mg} / \mathrm{kg})$ administered alone, as measured with FPIA, were $0.752 \pm$ $0.112 \mu \mathrm{g} / \mathrm{ml}(\mathrm{n}=8)$ and did not differ from those for PHT $(5.53 \mathrm{mg} / \mathrm{kg})$ in combination with RTG $(17.19 \mathrm{mg} / \mathrm{kg})$, which were $0.801 \pm 0.157 \mu \mathrm{g} / \mathrm{ml}(\mathrm{n}=8)$ (Figure 2A). Similarly, total brain concentrations of RTG (17.19 mg/kg) administered singly, as measured with HPLC, were $11.24 \pm 0.34 \mu \mathrm{g} / \mathrm{ml}(\mathrm{n}=8)$ and did not differ from those for RTG (17.19 mg/kg) combined with PHT (5.53 mg/kg), which amounted to $10.12 \pm 0.65 \mu \mathrm{g} / \mathrm{ml}$ (n=8) (Figure 2B).

A

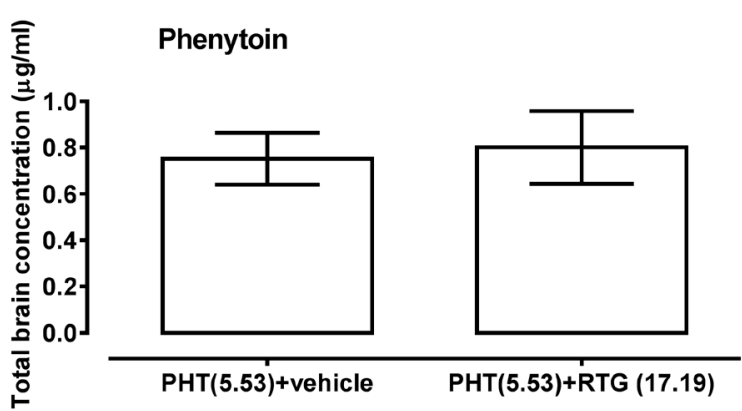

B

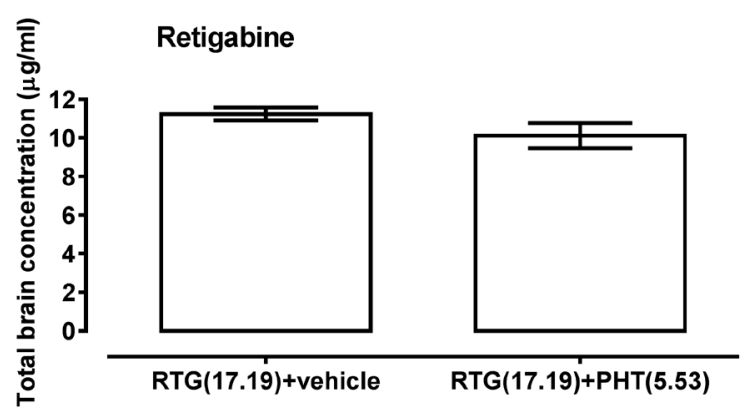

Figure 2A-B. Effects of retigabine (RTG) and phenytoin (PHT) on their mutual total brain concentrations in mice. Columns represent means \pm S.E.M. of at least 8 separate determinations $(n=8)$. Total brain concentrations of AEDs were determined either with fluorescence polarization immunoassay technique (PHT; Fig. 2A) or with high-pressure liquid chromatography (RTG; Fig. 2B). Data were statistically verified using the unpaired Student's t-test 


\section{Discussion}

In this study we found that RTG combined with PHT exerted additive interaction with regards to their anticonvulsant and acute adverse (neurotoxic) effects, as assessed in the MES and chimney tests, respectively. The benefit index (BI) values for the combination of RTG with PHT ranged between 1.16 (for the fixed-ratio of 1:1) and 1.50 (for the fixed-ratio of 3:1), indicating both, neutral and favorable combinations between these AEDs. Theoretically, AEDs' combinations can be classified as: beneficial, neutral and unfavorable, depending on the BI values. In isobolography, it is widely accepted that the BI value higher than 1.3 illustrates advantageous combination. In contrast, the BI value lower than 0.7 documents unfavorable combination. Neutral combination is reported if its $\mathrm{BI}$ value is ranging from 0.7 to 1.3 [13]. The calculation of BI values for AED combinations in preclinical studies can really help clinicians to make a right decision about the selection of adequate AEDs' combinations. It can be postulated that the calculation of BI values should be obligatory for all AED combinations tested in both seizure models and behavioral tests evaluating adverse (neurotoxic) effects in animals.

Previously, it has been reported that the combinations of valproate+carbamazepine [20], and lamotrigine+felbamate (BI = 1.08-1.46) [16] exerted additivity in the mouse MES model and sub-additivity (antagonism) in the rotarod or chimney test. On the other hand, the combination of topiramate+felbamate exerted synergistic interaction in the mouse MES test and antagonistic interaction in the chimney test (BI $=1.90-2.59)$ [13]. Similarly, the combination of topiramate+oxcarbazepine producing synergy in the mouse MES model and additivity in the chimney test, has also been classified as favorable (BI $=1.35-1.71)$ [13]. In contrast, the combinations of oxcarbazepine+felbamate $(\mathrm{BI}=0.53-0.71)$, and oxcarbazepine+lamotrigine $(\mathrm{BI}=0.43-0.54)$ have been classified as unfavorable due to their antagonistic interaction in the mouse MES model and additive or synergistic interaction in the chimney test, respectively [13].

The results from this study, displaying the additive interaction between RTG and PHT in the mouse MES model, are generally in agreement with those reporting additive interaction for the combinations of RTG with carbamazepine and lamotrigine in the mouse MES model [8]. Similarly, it has lately been demonstrated that the interaction between RTG and oxcarbazepine (another AED) was additive in the mouse MES model (unpublished data). Since carbamazepine, lamotrigine, oxcarbazepine and PHT possess similar mechanisms of action related with the blockade of voltage-gated sodium channels [21], it is not surprising that their interactions with RTG in the mouse MES model were similar (additive). In contrast, a supra-additive (synergistic) interaction was observed for the combinations of RTG with levetiracetam and valproate in the mouse MES model [8,9]. In these cases, molecular mechanisms of action of levetiracetam and valproate are totally different from those for carbamazepine, lamotrigine, oxcarbazepine and PHT.

It is important to note that pharmacokinetic estimation of total brain concentrations of RTG and PHT revealed that neither RTG, nor PHT affected mutually their total brain concentrations in mice. This pharmacokinetic study allowed us to entirely exclude any pharmacokinetic interactions between the AEDs and, simultaneously, confirm pharmacodynamic nature of the investigated interaction in the mouse MES model.

\section{Conclusions}

If the results from this study could be translated to clinical trials, the combination of RTG with PHT might be beneficial for patients remaining refractory to currently available AEDs [22].

\section{Acknowledgements}

This study was supported by a research grant from GlaxoSmithKline (Brentford, UK). The generous gift of retigabine from GlaxoSmithKline (Brentford, UK) is gratefully acknowledged. The authors express their thanks to Dr. G. Raszewski (Institute of Rural Health, Lublin, Poland) for the skillful determination of the brain concentrations of retigabine.

\section{References:}

1. Kwan P, Schachter SC, Brodie MJ. Drug-resistant epilepsy. New Eng J Med. 2011; 365: 919-926.

2. Kwan P, Brodie MJ. Combination therapy in epilepsy: when and what to use. Drugs. 2006; 66: $1817-1829$.

3. Kozak M, Sobczak P, Żukiewicz-Sobczak W. Health properties of selected herbal plants. Health Probl Civil. 2016; 10: 64-70. 
4. Kondrat-Wróbel MW, Łuszczki JJ. Interaction of three-drug combination of lacosamide, carbamazepine and phenobarbital in the mouse maximal electroshock-induced seizure model - an isobolographic analysis. Health Probl Civil. 2016; 10: 55-61.

5. European Medicines Agency Trobalt : EPAR - Product Information. [Internet]. 2016 [last updated 23 June 2016]; [about 119 p.]. Available from: http://www.ema.europa.eu/ema/index.jsp?curl=pages/medicines/human/medicines/001245/human_med_001431.jsp\&mid=WC0b01ac058001d124.

6. Rundfeldt C, Netzer R. Investigations into the mechanism of action of the new anticonvulsant retigabine. Interaction with GABAergic and glutamatergic neurotransmission and with voltage gated ion channels. Arzneimittelforschung. 2000; 50: 1063-1070.

7. Treven M, Koenig X, Assadpour E, Gantumur E, Meyer C, Hilber K, et al. The anticonvulsant retigabine is a subtype selective modulator of GABAA receptors. Epilepsia. 2015; 56: 647-657.

8. Luszczki JJ, Wu JZ, Raszewski G, Czuczwar SJ. Isobolographic characterization of interactions of retigabine with carbamazepine, lamotrigine, and valproate in the mouse maximal electroshock-induced seizure model. Naunyn Schmiedebergs Arch Pharmacol. 2009; 379: 163-179.

9. Luszczki JJ, Zagaja M, Miziak B, Florek-Luszczki M, Czuczwar SJ. Synergistic interaction of retigabine with levetiracetam in the mouse maximal electroshock-induced seizure model: a type II isobolographic analysis. Pharmacology. 2015; 96: 11-15.

10. Lerche H, Daniluk J, Lotay N, DeRossett S, Edwards S, Brandt C. Efficacy and safety of ezogabine/retigabine as adjunctive therapy to specified single antiepileptic medications in an open-label study of adults with partial-onset seizures. Seizure. 2015; 30: 93-100.

11. Loscher W, Fassbender CP, Nolting B. The role of technical, biological and pharmacological factors in the laboratory evaluation of anticonvulsant drugs. II. Maximal electroshock seizure models. Epilepsy Res. 1991; 8: 79-94.

12. Loscher W, Nolting B. The role of technical, biological and pharmacological factors in the laboratory evaluation of anticonvulsant drugs. IV. Protective indices. Epilepsy Res. 1991; 9: 1-10.

13. Luszczki JJ, Czuczwar SJ. Preclinical profile of combinations of some second-generation antiepileptic drugs: an isobolographic analysis. Epilepsia. 2004; 45: 895-907.

14. Litchfield JT Jr, Wilcoxon F. A simplified method of evaluating dose-effect experiments. J Pharmacol Exp Ther. 1949; 96: 99-113.

15. Luszczki JJ. Isobolographic analysis of interaction for three-drug combination of carbamazepine, phenobarbital and topiramate in the mouse maximal electroshock-induced seizure model. Pharmacology. 2016; 97: 259-264.

16. Luszczki JJ, Czuczwar SJ. Interaction between lamotrigine and felbamate in the maximal electroshock-induced seizures in mice: an isobolographic analysis. Eur Neuropsychopharmacol. 2005; 15: 133-142.

17. Boissier JR, Tardy J, Diverres JC. Une nouvelle méthode simple pour explorer l'action «tranquillisante»: le test de la cheminée. Pharmacology. 1960; 3: 81-84.

18. Tallarida RJ. Quantitative methods for assessing drug synergism. Genes Cancer. 2011; 2: 1003-1008.

19. Tallarida RJ. Revisiting the isobole and related quantitative methods for assessing drug synergism. J Pharmacol Exp Ther. 2012; 342: 2-8.

20. Bourgeois BF. Anticonvulsant potency and neurotoxicity of valproate alone and in combination with carbamazepine or phenobarbital. Clin Neuropharmacol. 1988; 11: 348-359.

21. Czapinski P, Blaszczyk B, Czuczwar SJ. Mechanisms of action of antiepileptic drugs. Curr Top Med Chem. 2005; 5: 3-14.

22. Brodie MJ, Sills GJ. Combining antiepileptic drugs--rational polytherapy? Seizure. 2011; 20: 369-375. 